\title{
ANALISIS FAKTOR-FAKTOR YANG MEMPENGARUHI BEHAVIORAL INTENTION APLIKASI DELIVERY SERVICE FOOD\&BEVERAGE
}

\author{
Hayu Gathut A.S. ${ }^{1}$ \\ Universitas Multimedia Nusantara \\ hayu@student.umn.ac.id \\ Purnamaningsih Purnamaningsih ${ }^{2}$ \\ Universitas Multimedia Nusantara \\ purnamaningsih@umn.ac.id
}

Diterima 24 Mei 2021

Disetujui 19 Juni 2021

\begin{abstract}
During the Covid-19 pandemic, the food and beverage industry, especially coffee consumption, increased by 44\% from 2008-2019. This is also supported by the increasing number of coffee shops with the coffee to go concept, namely coffee shops that are built with simple outlets and focus on serving take away. Fore Coffee is a coffee shop with the concept of coffee to go. During the Covid-19 pandemic, several outlets of Fore Coffee were closed. Facing this circumtance Fore Coffee focused on selling through online media, including applications. However, in 2020 data shows that the performance of the Fore Coffee app has decreased. This of course had an impact on the sales of Fore Coffee. Therefore, the aim of this research is to increase consumer desire to use the Fore Coffee application. Fourteen hypotheses will be tested in this study. The data will be analyzed by using a structural equation model (SEM). The samples analyzed were 145 samples. The results of this study indicate that time saving orientation and price saving orientation have a positive influence on post-usage usefulness and post-usage usefulness has an influence on attitude towards online food delivery services, and behavioral intention. Meanwhile, hedonic motivation and prior online purchase experience have no influence on behavioral intention. Managerial implications will be discussed in depth in this study.
\end{abstract}

Keywords: Convenience; Post-Usage Usefulness; Attitude; Behavioral Intention

\section{PENDAHULUAN}

\subsection{Latar Belakang}

Industri makanan dan minuman merupakan salah satu industri yang masih dapat tumbuh di masa pandemic Covid-19. Berdasarkan data dari Badan Pusat Statistik (BPS) industri makanan dan minuman tumbuh sebesar $0.22 \%$ pada triwulan II tahun 2020. Peningkatan ini didukung oleh beberapa komoditas yang merupakan unggulan antara lain mie, kopi dan produk olahan ikan (Akbar, 2020). Khususnya untuk komoditas kopi, berdasarkan data dari International Coffee Organization (ICO), diketahui bahwa konsumsi kopi di Indonesia meningkat sebesar 44\% dari tahun 2008 sampai dengan 2019 (Dinda, 2020).

Peningkatan jumlah konsumsi kopi di Indonesia, tidak terlepas dari meningkatnya jumlah kedai kopi yang mencapai 2.950 gerai di tahun 2019, dengan market value yang dihasilkan mencapai Rp 4.8 triliun market (Dahwilani, 2019). Salah satu jenis kedai kopi yang banyak 
muncul di Indonesia saat ini adalah kedai kopi dengan konsep Coffee to Go yaitu konsep berjualan kopi dengan kedai yang sederhana, dan pembeli umumnya membeli kopi untuk dibawa pulang atau dikonsumsi diperjalanan (Mediaindonesia, 2019). Beberapa kedai kopi Coffee to Go yang dikenal adalah Janji Jiwa, Kopi Kenangan, Tuku dan Fore Coffee.

Selama masa pandemic Covid-19 dimana seluruh aktivitas kita dibatasi, hal ini tentu saja juga berdampak pada penjualan kedai kopi dengan konsep Coffee to Go. Salah satu kedai kopi yang terkena dampak adalah Fore Coffee. Selama masa pandemic Covid-19 Foree Coffee harus menutup 20 kedai kopinya (Nurdiana, 2020). Guna mempertahankan bisnisnya Fore Coffee lebih mengutamakan penjualan secara online, selain menjual beberapa produk kopi kemasan satu liter dibeberapa platform marketplace, Fore Coffee juga berupaya untuk meningkatkan penjualan melalui aplikasi yang dimiliki, mengingat pembatasan di masa pandemic covid ini membuat konsumen lebih menyukai berbelanja makanan dan minuman secara online (Nordiansyah, 2021). Hal ini sejalan pula dengan hasil survei dari Nielsen yang menyatakan bahwa 58\% masyarakat Indonesia menyukai memesan makanan dan minuman melalui aplikasi di ponsel mereka (Thomas, 2019).

Strategi ini merupakan salah satu upaya yang dilakukan oleh Fore Coffee meskipun tidak mudah, mengingat beberapa pesaing dengan konsep Coffee to Go sejenis juga memiliki upaya yang sama seperti Kopi Kenangan dan Janji Jiwa (Yusra, 2020). Untuk aplikasi Fore Coffee yang sudah diluncurkan sejak September 2018 sampai dengan tahun 2019 telah memiliki 1.5 juta pengguna yang telah mendaftar di akun Fore Coffee (Catarina, 2019). Namun berdasarkan analisis data yang diperoleh sampai dengan Agustus 2020, melalui websimiliarity pada gambar 1, terdapat penurunan jumlah downloads pada aplikasi Fore Coffee, sementara pesaing terdekat yaitu Kopi Kenangan memiliki trend jumlah pendownload yang semakin meningkat meskipun Kopi Kenangan baru membuat aplikasi sejak 16 Januari 2020.

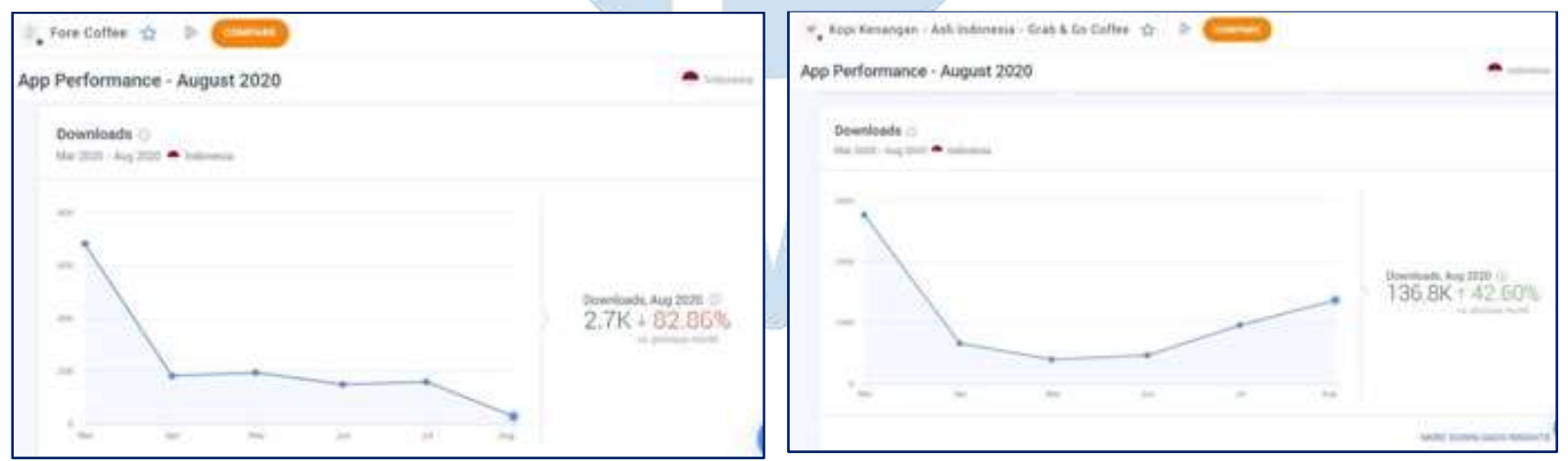

Gambar 1. App Peformance: Aplikasi Fore Coffee dan Kopi Kenangan per Agustus 2020

Sumber : similarweb.com

Oleh karena itu, dengan melihat trend penurunan app performance pada aplikasi Fore Coffee, maka penelitian ini bertujuan untuk meningkatkan keinginan konsumen untuk menggunakan aplikasi Fore Coffee untuk pembelian kopi. Diharapkan dengan meningkatnya jumlah pengguna aplikasi ini, dapat membantu peningkatan angka penjualan Fore Coffee di masa pandemic Covid-19.

Penelitian tentang motivasi yang mendasari konsumen untuk membeli produk secara online penting dilakukan, karena dapat menjadi dasar bagi perusahaan untuk membuat strategi pemasaran. Penelitian sebelumnya telah melihat bahwa convenience (Kimes, 2011), dan hedonic motivation (Saarijarvi et al., 2014) menjadi salah satu alasan konsumen untuk melakukan pembelian secara online (Yeo et al., 2017). Beberapa penelitian tentang 
pemanfaatan teknologi pada food delivery service telah dilakukan, seperti penelitian dari Suhartanto et al., (2019) yang melihat pengaruh faktor $e$-service quality terhadap loyalitas pada aplikasi food delivery service. Sementara penelitian lain dari Lee et al., (2017) melihat bahwa ease of use dan usefulness memberi pengaruh terhadap keinginan seseorang untuk menggunakan sebuah aplikasi. Serta beberapa penelitian lain dari Chen et al., (2019) dan Hwang et al., (2019) yang juga meneliti tentang food delivery service. Namun, masih belum banyak penelitian tentang aplikasi food delivery service yang menggunakan pendekatan perluasan model dari information technology continuance yang dirancang oleh Bhattacherjee et al., (2008), yang melihat pengaruh post usage usefulness terhadap behavioral intention (Yeo et al., 2017). Penelitian ini menggunakan beberapa variabel dari model information technology continuance yang merujuk pada penelitian Yeo et al. (2017) yang meliputi convenience, postusage usefulness, attitude, dan behavioral intention untuk melihat faktor-faktor yang mempengaruhi keinginan untuk menggunakan aplikasi.

\subsection{Tinjauan Pustaka}

\subsubsection{Hedonic Motivation terhadap Convenience Motivation}

Hedonic motivation diartikan sebagai kesenangan yang didapat ketika menggunakan sebuah teknologi, dan telah terbukti memiliki peran penting dalam menentukan untuk menerima atau tidak suatu teknologi (Venkatesh et al, 2012). Ketika seseorang sedang mencari produk makanan dan minuman yang diinginkan dengan memanfaatkan teknologi, mereka tidak hanya berharap mendapat kemudahan ketika mencari informasi, tetapi juga mendapatkan hiburan atau kesenengan dalam proses pencarian informasi tersebut. Menurut Chang et al., (2012) convenience motivation merupakan kemudahan yang dirasakan individu saat menggunakan sebuah teknologi.

Ketika pengguna merasa menikmati dalam proses pencarian informasi produk pada sebuah teknologi, maka pengguna akan merasa bahwa aplikasi tersebut memberikan kemudahan bagi penggunanya. Hal ini sejalan dengan penelitian dari Yeo et al., (2017), yang menyatakan bahwa hedonic motivations memiliki pengaruh positif terhadap convenience motivation. Hal yang sama juga ditemukan oleh Bendary \& Al-Sahouly (2018) bahwa hedonc motivation memengaruhi convenience motivation secara positif.

\section{H1 : Hedonic Motivation memiliki pengaruh positif terhadap Convenience Motivation.}

\subsubsection{Hedonic Motivation terhadap Post-Usage Usefulness}

Menurut Dennis et al., (2010) usefulness merupakan persepsi individu bahwa menggunakan teknologi baru akan meningkatkan pengalaman individu terhadap sebuah teknologi. Sejalan dengan hal tersebut menurut Teo \& Noyes (2011) post-usage usefulness adalah sejauh mana seorang individu akan percaya bahwa ketika menggunakan suatu teknologi akan meningkatkan produktivitasnya.

Ketika seorang konsumen menggunakan sebuah aplikasi dan merasa terhibur maka aspek hedonic motivation akan muncul yaitu kesenangan yang didapatkan ketika menggunakan sebuah teknologi (Venkates et al., 2012). Hal ini menggambarkan bahwa ketika menggunakan sebuah aplikasi untuk memesan makanan dan minuman, pengguna merasa bahwa aplikasi tersebut menyenangkan ketika digunakan, maka pengguna akan merasa bahwa aplikasi tersebut dapat membuat pengguna merasa lebih mudah untuk mencari makanan dan minuman yang diinginkan.

Hal ini sejalan dengan temuan dari Bendary \& Al-Sahouly (2018) yang menyatakan bahwa hedonic motivation memengaruhi post-usage usefulness secara positif. 
H2 : Hedonic Motivation memiliki pengaruh positif terhadap Post-Usage Usefulness.

\subsubsection{Prior Online Purchase Experience terhadap Convenience Motivation}

Pengalaman online sebelumnya yang dimiliki oleh pengguna cenderung memiliki tingkat ketidakpastian yang rendah terhadap keinginan membeli secara online, hal ini akan mendorong keinginan konsumen yang lebih tinggi untuk membeli produk secara online. Prior online purchase experience menurut Tong (2010) adalah pengalaman konsumen yang menggambarkan seberapa sering konsumen melakukan pembelian secara online. Pengalaman online ini dapat berupa pembelian produk makanan dan minuman dengan menggunakan sebuah aplikasi. Sedangkan online buying experience dapat diartikan sebagai seberapa sering seorang individu menggunakan internet untuk berbelanja (Park \& Jun, 2003).

Untuk itu pengguna yang telah memiliki pengalaman sebelumnya dalam berbelanja secara online akan merasa bahwa teknologi tersebut dapat mengurangi upaya yang dilakukan untuk berbelanja makanan dan minuman melalui sebuah aplikasi. Ketika upaya yang dilakukan untuk menggunakan aplikasi tersebut tidak banyak, maka pengguna akan merasa bahwa aplikasi tersebut memberikan kemudahan. Hal ini sejalan dengan hasil penelitian dari Tong (2010) dan Saade \& Kira (2007) bahwa prio online experience memiliki pengaruh positif terhadap convenience motivation.

\section{H3 : Prior Online Purchase Experience memiliki pengaruh positif terhadap Convenience Motivation.}

\subsubsection{Prior Online Purchase Experience terhadap Post-Usage Usefulness}

Ketika seseorang telah memiliki pengalaman sebelumnya pada pembelian secara online dengan menggunakan sebuah teknologi, maka pengalaman tersebut dapat digunakan sebagai dasar untuk mengukur manfaat sebuah teknologi yang digunakan saat ini. Konsumen akan memiliki persepsi bahwa dengan menggunakan teknologi baru akan meningkatkan pengalaman individu tersebut (Dennis et al., 2010). Hal ini tentu saja akan menumbuhkan persepsi manfaat dari pengguna terhadap teknologi aplikasi yang digunakan melalui post-usage usefulness yaitu keyakinan pengguna terhadap efisiensi kerja yang dapat ditingkatkan dengan menggunakan aplikasi tertentu (Chang et al., 2012).

Berdasarkan penelitian yang dilakukan oleh Chen (2012), juga menyatakan bahwa prior online purchase experience memiliki pengaruh positif terhadap perceived usefulness. Hal yang sama juga ditemukan oleh Ramayah et al., (2013).

\section{H4 : Prior Online Purchase Experience memiliki pengaruh positif terhadap Post-Usage Usefulness.}

\subsubsection{Time Saving Orientation terhadap Convenience Motivation}

Mencari informasi produk secara online merupakan indikator terpenting dari perilaku pembelian online (Bellman et al., 1999). Selain itu jumlah waktu luang yang dimiliki, dengan meningkatnya jumlah jam kerja akan membuat waktu yang tersedia semakin sedikit untuk mencari dan membeli produk secara langsung dengan mengunjungi retail. Saat ini, konsumen mencoba mencari cara baru untuk menemukan informasi dan membeli barang, dengan lebih cepat dan nyaman. Di masa lalu konsumen lebih menyukai membeli produk dengan datang langsung ke toko fisik, sekarang sekarang lebih banyak memanfaatkan internet untuk menemukan informasi terkait produk yang diinginkan. Kim et al., (2015) mendefininisikan time saving sebagai penghematan waktu yang didapatkan ketika melakukan pembelian, mengunjungi toko atau berbelanja secara online. 
Teo \& Noyes (2011) mendefinisikan convenience motivation sebagai sejauh mana seseorang percaya bahwa dengan menggunakan teknologi tertentu akan terbebas dari upaya. Berdasarkan penelitian yang dilakukan oleh Yeo et al., (2017), bahwa time saving orientation memiliki pengaruh positif terhadap convenience motivation. Hal ini menggambarkan bahwa jika suatu teknologi dapat menghemat waktu untuk bertransaksi, maka konsumen akan melihat bahwa teknologi tersebut dapat mengurangi upaya lebih dari penggunanya. Dalam penelitiannya Mohamed et al., (2014) juga menemukan hal serupa bahwa time saving orientation memengaruhi convenience motivation secara positif. Hasil tersebut juga sejalan dengan penelitian dari Hossain et al., (2019) yang menyatakan bahwa time saving orientation memiliki pengaruh positif terhadap convenience motivation.

\section{H5 : Time Saving Orientation memiliki pengaruh positif terhadap Convenience Motivation.}

\subsubsection{Time Saving Orientation terhadap Post-Usage Usefulness}

Ketika seseorang merasa dengan menggunakan sebuah teknologi seperti aplikasi untuk berbelanja dapat menghemat waktu yang dibutuhkan, maka konsumen merasa bahwa teknologi tersebut dapat memberikan manfaat bagi dirinya. Mengingat untuk saat ini lebih banyak konsumen yang tidak memiliki banyak waktu ketika berbelanja sehingga mereka lebih menginginkan hal yang sifatnya praktis dan cepat. Hal ini sejalan dengan temuan dari Yeo et al., (2017), yang menyatakan bahwa time saving orientation memiliki pengaruh positif terhadap post-usage usefulness, yang diperkuat pula dengan temuan dari Hossain et al., (2019) yang juga menyatakan hal yang sama. Time saving merupakan waktu yang dibutuhkan untuk melakukan pembelian, mengunjungi toko atau berbelanja secara online (Kim et al., 2015). Sedangkan post-usage usefulness sebagai keyakinan pengguna bahwa efisiensi kerja dapat diantisipasi dan ditingkatkan dengan sistem aplikasi tertentu (Chang et al., 2012).

H6 : Time Saving Orientation memiliki pengaruh positif terhadap Post-Usage Usefulness.

\subsubsection{Price Saving Orientation terhadap Convenience Motivation}

Lee et al., (2019) mendefinisikan price saving orientation sebagai manfaat yang dirasakan pengguna aplikasi terhadap biaya yang dikeluarkan ketika menggunakan sebuah aplikasi. Ketika pengguna aplikasi merasa bahwa teknologi yang digunakan dapat mengurangi besarnya pengeluaran ketika membeli sebuah produk, maka konsumen merasa bahwa teknologi tersebut memberikan kemudahan. Kemudahan yang dirasakan penggunanya ini termasuk dalam convenience motivation (Chang et al., 2012). Hal ini sejalan dengan temuan dari Mohamed et al., (2014) bahwa price saving orientation memengaruhi convenience motivation secara positif dan Novita \& Husna (2020) yang menemukan hal yang sama.

H7 : Price Saving Orientation memiliki pengaruh positif terhadap Convenience Motivation.

\subsubsection{Price Saving Orientation terhadap Post-Usage Usefulness}

Ketika seseorang menggunakan sebuah aplikasi dalam membeli suatu produk, dan melalui aplikasi tersebut konsumen memperoleh beberapa penawaran menarik seperti harga produk yang lebih rendah karena adanya program sales promotion, atau biaya pengiriman yang lebih murah maka konsumen merasa bahwa aplikasi tersebut dapat mendukung price saving orientation, yaitu manfaat yang dirasakan dari penggunaan aplikasi terhadap dampak finansial yang harus dikeluarkan ketika menggunakan aplikasi (Lee et al., 2019). Ketika konsumen merasa bahwa aplikasi tersebut memberikan keuntungan dari sisi penghematan biaya 
pembelian, maka konsumen merasa bahwa aplikasi tersebut memberikan manfaat. Penelitian dari Mohamed et al., (2014) mendukung pernyataan tersebut bahwa price saving orientation memengaruhi post-usage usefulness secara positif. Temuan lain yaitu dari penelitian Wei et al., (2018), menyatakan hal yang sama bahwa price saving orientation memilki pengaruh positif terhadap post-usage usefulness.

\section{H8 : Price Saving Orientation memiliki pengaruh positif terhadap Post-Usage Usefulness.}

\subsubsection{Convenience Motivation terhadap Post-Usage Usefulness}

Rodrigues et al., (2016) menyatakan bahwa convenience motivation memiliki pengaruh positif terhadap post-usage usefulness. Hal ini menggambarkan bahwa ketika seorang konsumen merasakan kemudahan ketika menggunakan sebuah aplikasi, seperti kemudahan dalam memesan, memilih produk maupun pembayaran maka konsumen merasa bahwa teknologi yang digunakan dapat memberikan manfaat. Hal ini diperkuat pula dengan temuan dari Xu et al., (2012), yang menyatakan bahwa convenience motivation memilki pengaruh positif terhadap post-usage usefulness. Menurut Chang et al., (2012) post-usage usefulness merupakan persepsi pengguna terkait efisiensi kerja yang dapat ditingkatkan dengan menggunakan sistem aplikasi tertentu.

\section{H9 : Convenience Motivaiton memiliki pengaruh positif terhadap Post-Usage Usefulness.}

\subsubsection{Convenience Motivation terhadap Attitude Towards Online Food Delivery Services}

Hasil penelitian yang dilakukan oleh Nedra et al., (2019) menunjukan bahwa convenienve motivation memiliki pengaruh positif terhadap attitude. Hal yang sama juga disampaikan oleh Kim (2016) yang menyatakan bahwa convenienve motivation memiliki pengaruh positif terhadap attitude. Hal ini menggambarkan bahwa ketika konsumen merasa bahwa menggunakan sebuah teknologi aplikasi dapat memberikan kemudahan dalam melakukan pembelian secara online, maka pada persepsi konsumen akan terbentuk sikap yang positif terhadap aplikasi tersebut. Sikap positif yang muncul pada konsumen seperti rasa suka ketika menggunakan aplikasi tersebut dalam kehidupan sehari-hari. Menurut Park\&Kim (2013), attiude adalah perasaan positif atau negatif konsumen terhadap situs web atau aplikasi untuk melakukan pemesanan.

\section{H10 : Convenience Motivation memiliki pengaruh positif terhadap Attitude Towards Online Food Delivery Services}

\subsubsection{Convenience Motivation terhadap Behavioral Intention}

Chang et al., (2012) mendefinisikan convenience motivation sebagai tingkat kemudahan yang dirasakan individu saat menggunakan sebuah sistem. Teo \& Noyes (2011) mendefinisikan convenience motivation sebagai sejauh mana seseorang percaya bahwa dengan menggunakan teknologi tertentu akan terbebas dari upaya. Sedangkan behavioral Intention merupakan keinginan individu dalam menggunakan teknologi (Li \& Cai 2012), sedangkan menurut Venkatesh, (2003) behavioral intention adalah keinginan menggunakan sebuah teknologi dimasa yang akan datang.

Berdasarkan penelitian yang dilakukan oleh Yeo et al., (2017), bahwa convenience memiliki pengaruh positif terhadap behavioral intention. Menurut penelitian yang dilakukan oleh Sun \& Zhang (2006) dan Fagan et al., (2008) convenience motivation juga memiliki pengaruh positif terhadap behavioral intention. Hal ini menggambarkan bahwa kemudahan yang dirasakan ketika menggunakan sebuah aplikasi dapat mendorong keinginan seseorang untuk menggunakan aplikasi tersebut dalam jangka panjang. 
H11 : Convenience Motivation memiliki pengaruh positif terhadap Behavioral Intention

\subsubsection{Post-Usage Usefulness terhadap Attitude Towards Online Food Delivery Services}

Menurut penelitian yang dilakukan oleh Kim \& Forsythe (2010) perceived usefulness memiliki pengaruh positif terhadap attitude. Hasil penelitian tersebut dapat menggambarkan bahwa ketika konsumen merasakan manfaat dalam menggunakan sebuah aplikasi, seperti dapat menghemat waktu dalam proses pencarian produk, kemudahan dalam mendapatkan informasi tentang produk baru, maupun kemudahan dalam hal pembayaran. Maka pada diri konsumen akan terbentuk sikap positif terkait dengan aplikasi tersebut. Hal ini seperti juga temuan dari Liu \& Li (2011) yang menyatakan bahwa perceived use fulness memiliki pengaruh positif terhadap attitude. Temuan serupa juga dibuktikan oleh penelitian dari Yeo et al., (2017).

\section{H12 : Post-Usage Usefulness memiliki pengaruh positif terhadap Attitude Towards} Online Food Delivery Services.

\subsubsection{Post-Usage Usefulness terhadap Behavioral Intention}

Li \& Huang (2009) menyatakan bahwa post-usage usefulness memiliki pengaruh positif terhadap behavioral intention. Hal yang sama juga ditemukan oleh Purnamaningsih et al., (2019) yang menyatakan bahwa post-usage usefulness memiliki pengaruh positif terhadap behavioral intention pada pengguna aplikasi. Konsumen yang merasakan sebuah manfaat dari penggunaan sebuah aplikasi dalam mempermudah proses pembelian barang maupun pembayaran, maka kemudahan yang dirasakan tersebut dapat mendorong keinginan konsumen untuk menggunakan aplikasi tersebut. Ernst et al., (2013) juga menyatakan hal yang sama bahwa post-usage usefulness memiliki pengaruh positif terhadap behavioral intention.

Menurut Li \& Cai (2012) behavioral intention merupakan perilaku individu yang direncanakan dimasa depan, hal ini didukung pula oleh penelitian Venkatesh (2003) yang menyatakan bahwa behavioral intention adalah keinginan menggunakan sebuah teknologi dimasa yang akan datang. Meskipun Venkatesh (2012) pada penelitian selanjutnya menyatakan bahwa behavioral intention adalah keinginan untuk menggunakan kembali teknologi dalam jangka panjang. Namun pada penelitian ini merujuk pada Venkatesh (2003), yang didukung pula oleh Partridge et al., (2020) yang menyatakan bahwa behavioral intention mendorong keinginan konsumen untuk melakukan pemesanan makanan melalui sebuah aplikasi. Sedangkan menurut Teo \& Noyes (2011) post-usage usefulness merupakan keyakinan dari seorang individu bahwa teknologi akan mempermudah aktivitasnya.

\section{H13 : Post-Usage Usefulness memiliki pengaruh positif terhadap Behavioral Intention}

\subsubsection{Attitude Towards Online Food Delivery Services terhadap Behavioral Intention}

Attitude towards online food delivery services merupakan evaluasi positif atau negatif konsumen terhadap sebuah teknologi aplikasi yang dapat mempermudah pemesanan makanan atau minuman secara online. Pengertian tersebut merujuk pada penelitian Park \& Kim, (2013) dan Partridge et al., (2020). Sedangkan menurut Li\&Cai, (2012) dan Venkatesh, (2003) behavioral intention adalah perilaku individu dalam memanfaatkan teknologi dimasa yang akan datang. Hal ini akan mendorong rencana individu untuk menggunakan teknologi aplikasi ketika melakukan pemesanan makanan atau minuman yang akan dilakukan dimasa yang akan datang (Partridge et al 2020).

Ketika konsumen memiliki pengalaman positif terhadap sebuah teknologi aplikasi, maka akan muncul sikap positif terhadap aplikasi tersebut. Sikap positif tersebut seperti rasa suka atau senang ketika menggunakan aplikasi. Rasa suka tersebut, ahirnya akan mendorong keinginan konsumen untuk menggunakan aplikasi tersebut untuk melakukan pembelian. Hal 
ini diperkuat dengan temuan dari Liu \& Li (2011) dan Lee et al., (2006) yang menyatakan bahwa attitude memiliki pengaruh positif terhadap behavioral intention.

H14 : Attitude Towards Online Food Delivery Services memiliki pengaruh positif terhadap Behavioral Intention

\subsection{Model Penelitian}

Pada penelitian ini, model penelitian yang digunakan merujuk pada peneltian Yeo et al., (2017) dengan delapan variabel seperti pada gambar 2

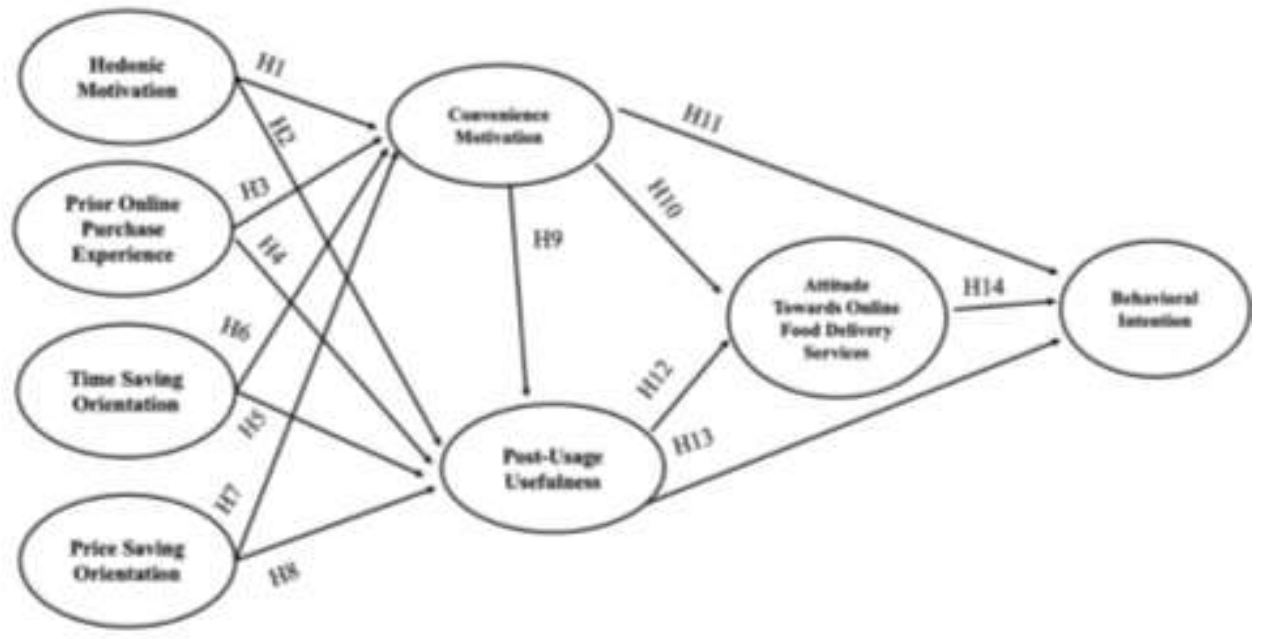

Gambar 2. Model Penelitian

\section{METODOLOGI PENELITIAN}

\subsection{Desain Penelitian dan Sampel}

Desain penelitian yang digunakan pada penelitian ini adalah penelitian deskriptif, yang ingin melihat gambaran secara umum dari pasar (Hair et al., 2010). Metode survei digunakan pada penelitian ini dengan menyebarkan kuesioner secara online. Pemilihan online kuesioner dirasa lebih sesuai mengingat dimasa pandemic Covid-19 diberlakukan pembatasan interkasi fisik secara langsung, sehingga untuk menjangkau responden dapat dilakukan secara online. Jumlah sampel yang dibutuhkan pada penelitian ini ditentukan dengan banyaknya indikator pertanyaan yang digunakan pada penelitian ini dikali dengan 5 (Hair et al., 2010). Indikator yang digunakan sebanyak 29 indikator pertanyaan, sehingga minimum responden yang dibutuhkan adalah 145 responden. Keseluruhan data yang diperoleh adalah 338 responden, namun hanya 145 responden yang memenuhi kriteria atau lolos screening sebagai responden. Adapun kriteria responden dalam penelitian ini adalah orang yang pernah membeli Fore Coffee secara langsung di retail, mengetahui dan pernah mengakses aplikasi Fore Coffee tetapi belum pernah membeli kopi melalui aplikasi Fore Coffee. Teknik pengambilan sampel yang digunakan non-probability sampling dengan teknik judgemental sampling, karena sampel yang dipilih berdasarkan kriteria yang mendalam terkait objek penelitian yaitu aplikasi Fore Coffee

\subsection{Pengukuran dan Pengumpulan Data}

Pada penelitian ini menggunakan delapan variabel, yang diukur oleh beberapa indikator yang merujuk pada beberapa penelitian sebelumnya seperti ditunjukan pada tabel 3.1. 
Tabel 1. Konstruk Variabel

\begin{tabular}{|c|c|c|}
\hline Variabel & $\begin{array}{l}\text { Indikator } \\
\text { Pertanyaan }\end{array}$ & Sumber \\
\hline Hedonic Motivation & 4 & Yeo et al., (2017) dan Wang \& Gutierrez (2019) \\
\hline Prior online purchase experience & 3 & Yeo et al., (2017), Ling et al., (2010) \\
\hline Time Saving Orientations & 3 & Yeo et al., (2017) dan Kim et al., (2015) \\
\hline Price Saving Orientations & 3 & Lee et al., (2019) \& Chang et al., (2009). \\
\hline Conveniece Motivation & 4 & Chang et al., (2012). \\
\hline Post-Usage Usefulness & 4 & $\begin{array}{l}\text { Kim et al., (2010), Roh \& Park (2019) and } \\
\text { Driediger \& Bhatiasevi (2019) }\end{array}$ \\
\hline $\begin{array}{l}\text { Attitude Towards Online Food } \\
\text { Delivery Services }\end{array}$ & 4 & Yeo et al., (2017) \\
\hline $\begin{array}{l}\text { Behavioral Intention Towards } \\
\text { Online Food Delivery Services }\end{array}$ & 4 & $\begin{array}{l}\text { Escobar-Rodríguez \& Carvajal-Trujillo (2013) dan } \\
\text { Yeo et al., (2017). }\end{array}$ \\
\hline
\end{tabular}

Setiap indikator pertanyaan pada tabel 3.1 diukur dengan menggunakan skala likert 1-7, dengan angka 1 mewakili sangat tidak setuju dan angka 7 mewakili sangat setuju. Penggunaan skala likert 1 sampai dengan 7 karena peneliti menganggap bahwa responden memiliki pengetahuan yang baik terhadap objek penelitian

\subsection{Analisis Data}

Pada penelitian ini analisis data menggunakan metode structural equation model (SEM), dengan melihat analisis measurement model untuk melihat validitas dan reliablitas data, dan dilanjutkan structural model untuk melihat pengaruh antar variabel (Hair et al., 2010). Penelitian ini menggunakan analisis structural equation model karena ingin melihat pengaruh antar variabel secara simultan.

\section{HASIL PENELITIAN DAN DISKUSI}

\subsection{Statistik Deskriptif}

Pada penelitian ini seperti ditunjukan pada tabel 2 dari 145 responden mayoritas responden adalah pria (84\%), dengan usia antara 18-25 tahun (93\%), dengan profesi adalah mahasiswa $(92 \%)$.

Table 2. Profil Responden

\begin{tabular}{|l|l|r|r|}
\hline \multicolumn{2}{|c|}{ Keterangan } & Jumlah & Persentase \\
\hline Gender & Pria & 46 & $84 \%$ \\
\hline & Wanita & 99 & $68 \%$ \\
\hline & & & \\
\hline Usia & $18-25$ & 135 & $93 \%$ \\
\hline & $26-33$ & 7 & $5 \%$ \\
\hline & $34-41$ & 3 & $2 \%$ \\
\hline Profesi & & & \\
\hline & Karyawan & 9 & $6 \%$ \\
\hline & Mahasiswa/i & 133 & $92 \%$ \\
\hline & Pegawai Negeri & 1 & $1 \%$ \\
\hline & Wiraswasta & 2 & $1 \%$ \\
\hline
\end{tabular}

Sumber : Data analisis 2020 


\subsection{Uji Validitas dan Reliabilitas}

Hasil uji validitas dan reliabilitas pada tabel 3 menunjukan bahwa seluruh indikator dinyatakan valid karena memiliki factor loading untuk setiap indikator diatas 0.5 dengan $\mathrm{T}$ Value diatas 1.96 (Hair et al., 2010), selain itu hasil uji reliabilitas setiap indikator dinyatakan reliable dengan nila CR diatas 0.7 dan VE diatas 0.5 (Hair et al., 2010)

Tabel 3. Validitas dan Reliabilitas

\begin{tabular}{|c|c|c|c|c|c|c|c|}
\hline Variabel & Kode & $\begin{array}{l}\text { Standardized } \\
\text { Factor } \\
\text { Loading } \\
\geq 0.5 \\
\end{array}$ & $\begin{array}{c}\text { T-values } \\
\geq 1,96\end{array}$ & Hasil Uji & $\begin{array}{l}\text { Construct } \\
\text { Reliability } \\
\text { (CR) }\end{array}$ & $\begin{array}{l}\text { Average } \\
\text { Variance } \\
\text { Extract } \\
\text { (AVE) }\end{array}$ & $\begin{array}{c}\text { Hasil } \\
\text { Uji }\end{array}$ \\
\hline \multirow{4}{*}{$\begin{array}{l}\text { Hedonic } \\
\text { Motivation }\end{array}$} & HM1 & 0.91 & 14.09 & Valid & \multirow[t]{4}{*}{0.96244} & \multirow[t]{4}{*}{0.86507} & \multirow[t]{4}{*}{ Reliable } \\
\hline & HM2 & 0.90 & 13.86 & Valid & & & \\
\hline & HM3 & 0.96 & 15.51 & Valid & & & \\
\hline & HM4 & 0.95 & 15.43 & Valid & & & \\
\hline \multirow{3}{*}{$\begin{array}{l}\text { Prior Online } \\
\text { Purchase } \\
\text { Experience }\end{array}$} & POPE1 & 0.78 & 10.69 & Valid & \multirow[t]{3}{*}{0.75101} & \multirow[t]{3}{*}{0.50273} & \multirow[t]{3}{*}{ Reliable } \\
\hline & POPE2 & 0.66 & 8.01 & Valid & & & \\
\hline & POPE3 & 0.68 & 8.59 & Valid & & & \\
\hline \multirow{3}{*}{$\begin{array}{l}\text { Time Saving } \\
\text { Orientation }\end{array}$} & TSO1 & 0.64 & 8.06 & Valid & \multirow[t]{3}{*}{0.75277} & \multirow[t]{3}{*}{0.50460} & \multirow[t]{3}{*}{ Reliable } \\
\hline & TSO2 & 0.74 & 9.58 & Valid & & & \\
\hline & TSO3 & 0.74 & 9.99 & Valid & & & \\
\hline \multirow{3}{*}{$\begin{array}{l}\text { Price Saving } \\
\text { Orientation }\end{array}$} & PSO1 & 0.71 & 8.83 & Valid & \multirow[t]{3}{*}{0.75101} & \multirow[t]{3}{*}{0.50150} & \multirow[t]{3}{*}{ Reliable } \\
\hline & PSO2 & 0.69 & 8.92 & Valid & & & \\
\hline & PSO3 & 0.73 & 9.54 & Valid & & & \\
\hline \multirow{4}{*}{$\begin{array}{l}\text { Convenience } \\
\text { Motivation }\end{array}$} & CM1 & 0.71 & 9.05 & Valid & \multirow[t]{4}{*}{0.80210} & \multirow[t]{4}{*}{0.50346} & \multirow[t]{4}{*}{ Reliable } \\
\hline & $\mathrm{CM} 2$ & 0.68 & 8.87 & Valid & & & \\
\hline & CM3 & 0.72 & 9.36 & Valid & & & \\
\hline & CM4 & 0.73 & 9.43 & Valid & & & \\
\hline \multirow{4}{*}{$\begin{array}{l}\text { Post-Usage } \\
\text { Usefulness }\end{array}$} & PUU1 & 0.75 & 10.12 & Valid & \multirow[t]{4}{*}{0.80017} & \multirow[t]{4}{*}{0.50143} & \multirow[t]{4}{*}{ Reliable } \\
\hline & PUU2 & 0.76 & 10.32 & Valid & & & \\
\hline & PUU3 & 0.67 & 8.73 & Valid & & & \\
\hline & PUU4 & 0.65 & 8.24 & Valid & & & \\
\hline \multirow{4}{*}{$\begin{array}{l}\text { Attitude } \\
\text { Towards Online } \\
\text { Food Delivery } \\
\text { Services }\end{array}$} & ATOFDS1 & 0.66 & 8.45 & VALID & \multirow[t]{4}{*}{0.81016} & \multirow[t]{4}{*}{0.51698} & \multirow[t]{4}{*}{ Reliable } \\
\hline & ATOFDS2 & 0.70 & 9.15 & $V A L I D$ & & & \\
\hline & ATOFDS3 & 0.75 & 10.13 & VALID & & & \\
\hline & ATOFDS4 & 0.76 & 10.44 & VALID & & & \\
\hline \multirow{4}{*}{$\begin{array}{l}\text { Behavioral } \\
\text { Intention }\end{array}$} & BIOFDS1 & 0.70 & 9.18 & VALID & \multirow[t]{4}{*}{0.80117} & 0.50312 & Reliable \\
\hline & BIOFDS2 & 0.69 & 8.99 & VALID & & & \\
\hline & BIOFDS3 & 0.75 & 10.20 & VALID & & & \\
\hline & BIOFDS4 & 0.69 & 8.87 & VALID & & & \\
\hline
\end{tabular}

Sumber: Data analisis (2020)

\subsection{Uji Hipotesis dan Model Fit}

Pada tabel 4 menunjukan bahwa hasil uji kecocokan model menunjukan bahwa keseluruhan index dari Goodness of Fit yaitu RMSEA, CFI dan PNFI masuk dalam kategori acceptable fit yang menunjukan terdapat kesesuaian data dengan model penelitian

Tabel 4. Kecocokan Model (Goodness of Fit)

\begin{tabular}{|l|l|c|l|}
\hline Goodness Of Fit Index & Batas nilai Goodness Of Fit & Nilai & Hasil \\
\hline RMSEA & RMSEA $<0.08$ & 0.047 & Acceptable Fit \\
\hline CFI & CFI $\geq 0.95$ & 0.97 & Acceptable Fit \\
\hline PNFI & $0 \leq \mathrm{NFI} \leq 1$ & 0.92 & Acceptable Fit \\
\hline
\end{tabular}


Sumber: Data analisis (2020)

Untuk hasil uji hipotesis pada tabel 5 menunjukan bahwa $\mathrm{H} 1-\mathrm{H} 4$ data tidak mendukung hipotesis karena memiliki nilai t-value dibawah 1.65, yang menunjukan bahwa hedonic motivation dan prior online purchase experience tidak memiliki pengaruh terhadap convenience motivation dan post usage usefulness. Sedangkan H5 dan H6 memiliki nilai tvalue diatas 1.65 yang menunjukan bahwa time saving orientation memiliki pengaruh positif terhadap convenience motivation dan post usage usefulness. Pada penelitian ini price saving orientation tidak memiliki pengaruh positif terhadap convenience motivation $(\mathrm{H} 7)$ karena memiliki nilai t-value dibawah 1.65, namun berpengaruh positif terhadap post-usage usefulness (H8). Sedangkan untuk convenience motivation tidak memiliki pengaruh positif terhadap post usage usefulness (H9), attitude (H10) dan behavioral intention (H11) karena memiliki nilai tvalue dibawah 1.65. Sedangkan post usage usefulness terbukti memiliki pengaruh terhadap attitude (H12) dan attitude memiliki pengaruh terhadap behavioral intention (H14) dengan nilai t-value diatas 1.65. Sedangkan post-usage usefulness tidak memiliki pengaruh positif terhadap behavioral intention (H13) dengan nilai t-value dibawah 1.65 yang menyatakan bahwa data tidak mendukung hipotesis.

Table 5. Uji Hipotesis

\begin{tabular}{|l|c|c|c|c|}
\hline \multicolumn{1}{|c|}{ Hipotesis } & Estimates & t-value & t-table & Decision \\
\hline $\begin{array}{l}\text { H1 : Hedonic Motivation memiliki pengaruh positif } \\
\text { terhadap Convenience Motivation. }\end{array}$ & -0.01 & -0.06 & 1.65 & Not Supported \\
\hline $\begin{array}{l}\text { H2: Hedonic Motivation memiliki pengaruh positif } \\
\text { terhadap Post-Usage Usefulness. }\end{array}$ & -0.13 & 1.28 & 1.65 & Not Supported \\
\hline $\begin{array}{l}\text { H3: Prior Online Purchase Experience memiliki pengaruh } \\
\text { positif terhadap Convenience Motivation. }\end{array}$ & -0.06 & -0.42 & 1.65 & Not Supported \\
\hline $\begin{array}{l}\text { H4: Prior Online Purchase Experience memiliki pengaruh } \\
\text { positif terhadap Post-Usage Usefulness. }\end{array}$ & 0.06 & 0.41 & 1.65 & Not Supported \\
\hline $\begin{array}{l}\text { H5: Time Saving Orientation memiliki pengaruh positif } \\
\text { terhadap Convenience Motivation. }\end{array}$ & 0.71 & 3.78 & 1.65 & Supported \\
\hline $\begin{array}{l}\text { H6: Time Saving Orientation memiliki pengaruh positif } \\
\text { terhadap Post-Usage Usefulness. }\end{array}$ & 0.67 & 2.28 & 1.65 & Supported \\
\hline $\begin{array}{l}\text { H7: Price Saving Orientation memiliki pengaruh positif } \\
\text { terhadap Convenience Motivation. }\end{array}$ & 0.24 & 1.59 & 1.65 & Not Supported \\
\hline $\begin{array}{l}\text { H8: Price Saving Orientation memiliki pengaruh positif } \\
\text { terhadap Post-Usage Usefulness. }\end{array}$ & 0.37 & 2.37 & 1.65 & Supported \\
\hline $\begin{array}{l}\text { H9: Convenience Motivaiton memiliki pengaruh positif } \\
\text { terhadap Post-Usage Usefulness. }\end{array}$ & -0.19 & -0.74 & 1.65 & Not Supported \\
\hline $\begin{array}{l}\text { H10: Convenience Motivation memiliki pengaruh positif } \\
\text { terhadap Attitude. }\end{array}$ & 0.18 & 1.24 & 1.65 & Not Supported \\
\hline $\begin{array}{l}\text { H11: Convenience Motivation memiliki pengaruh positif } \\
\text { terhadap Behavioral Intention }\end{array}$ & 0.08 & 0.67 & 1.65 & Not Supported \\
\hline $\begin{array}{l}\text { H12: Post-Usage Usefulness memiliki pengaruh positif } \\
\text { terhadap Attitude }\end{array}$ & 0.71 & 4.05 & 1.65 & Supported \\
\hline $\begin{array}{l}\text { H13 : Post-Usage Usefulness memiliki pengaruh positif } \\
\text { terhadap Behavioral Intention }\end{array}$ & 0.30 & 1.51 & 1.65 & Not Supported \\
\hline $\begin{array}{l}\text { H14 : Attitude memiliki pengaruh positif terhadap } \\
\text { Behavioral Intention }\end{array}$ & 0.58 & 2.86 & 1.65 & Supported \\
\hline Sumb: Data anals 2050
\end{tabular}

Sumber: Data analisis 2020 


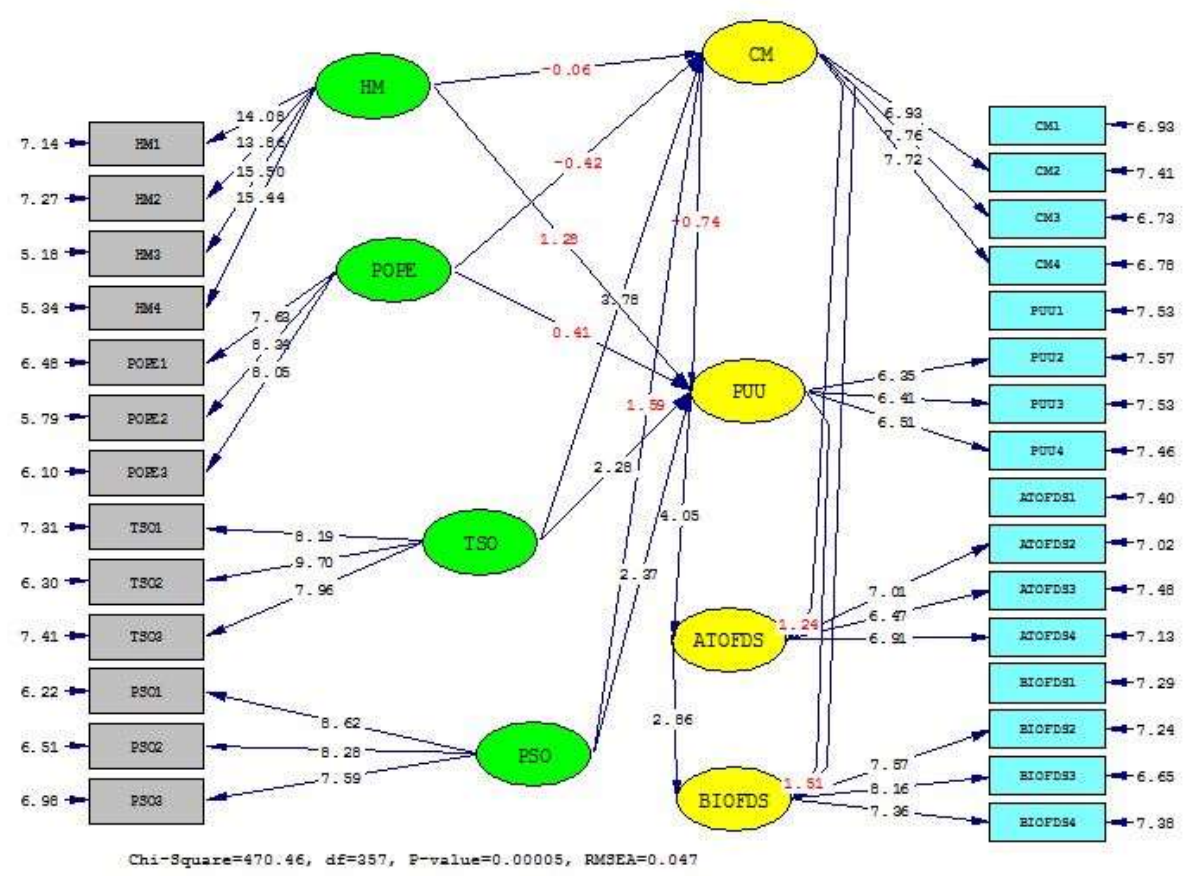

Gambar 3. Output Structural Model

\section{KESIMPULAN DAN SARAN}

\subsection{Kesimpulan}

Penelitian ini memiliki tujuan untuk meningkatkan keinginan konsumen dalam menggunakan aplikasi Fore Coffee ketika melakukan pembelian minuman kopi. Dari hasil analisis data menunjukan bahwa time saving orientation memiliki pengaruh positif terhadap post usage usefulness. Hal ini seperti halnya dinyatakan oleh Kimes (2011) bahwa konsumen memilih untuk menggunakan jasa layanan online delivery karena melihat beberapa manfaat yang dirasakan seperti lebih mudah ketika memesan dan melakukan pembayaran, sehingga tidak membutuhkan banyak waktu untuk mendapatkan produk yang diinginkan. Mengingat produk minuman kopi merupakan produk low involvement sehingga tidak dibutuhkan upaya dan proses pencarian informasi yang lebih banyak. Sehingga hal utama yang ingin didapatkan konsumen dari sebuah layanan aplikasi pemesanan minuman adalah kemudahan sehingga tidak membuang waktu konsumen. Temuan ini sejalan dengan temuan dari Hossain et al., (2019) yang menyatkan bahwa time saving orientation memiliki pengaruh positif terhadap perceived usefulness. Wei et al., (2018) dan Yeo et al., (2017) dalam penelitiannya juga menemukan hal yang sama bahwa ketika sebuah teknologi yang digunakan dapat menghemat waktu, maka pengguna akan merasa bahwa teknologi tersebut memiliki manfaat pada aktivitas sehari-hari.

Selain time saving orientation terdapat variabel lain yang memiliki pengaruh terhadap manfaat yang dirasakan konsumen ketika membeli minuman kopi menggunakan aplikasi yaitu price saving orientation. Pada price saving orientation konsumen melihat bahwa tawaran sales promotion melalui aplikasi menjadi sebuah daya tarik tersendiri. Hal ini menurut Madan \& Suri, (2001) menyatakan bahwa potongan harga yang diberikan dapat meningkatkan value dari suatu produk dimata konsumen. Mengingat value yang dirasakan konsumen akan semakin tinggi jika pengorbanan yang harus dikeluarkan semakin kecil. Meskipun minuman kopi merupakan produk low involment, pada dasarnya konsumen menginginkan mendapatkan produk yang dapat memberikan manfaat yang maksimum. Oleh karena itu, pada penelitian ini price saving orientation memiliki pengaruh positif terhadap manfaat yang dirasakan oleh 
konsumen ketika menggunakan aplikasi atau post usage usefulness. Temuan ini diperkuat oleh hasil penelitian dari Mohamed et al., (2014) dan Wei et al., (2018) yang menyatakan bahwa price saving orientation memiliki pengaruh positif terhadap perceived usefulness.

Pada penelitian ini juga ditemukan bahwa time saving orientation juga memiliki pengaruh positif terhadap convenience motivation. Temuan ini sejalan dengan penelitian dari Hossain et al., (2019), bahwa time saving orientation memiliki pengaruh positif terhadap perceived ease of use. Hal ini menggambarkan bahwa ketika sebuah aplikasi menawarkan kemudahan dalam pemesanan minuman kopi, sehingga tidak membutuhkan waktu lama untuk mendapatkan minuman tersebut seperti harus menggunjungi langsung restoran dan menunggu proses pembuatan minuman, maka konsumen akan merasa bahwa aplikasi tersebut dapat memberikan kemudahan dalam mendukung aktivitas sehari-hari. Meskipun time saving orientation pada penelitian ini memiliki pengaruh positif terhadap convenience motivation, namun hasil yang berbeda ditunjukan pada variabel price saving orientation. Pada penelitian ini price saving orientation tidak memiliki pengaruh terhadap convenience motivation seperti pada temuan Prabowo \& Nugroho (2019). Penawaran harga minuman kopi yang lebih murah tentu saja tidak menggambarkan kemudahan yang dirasakan ketika membeli sebuah kopi melalui sebuah aplikasi. Mengingat kemudahan mengakses sebuah aplikasi ditentukan oleh fitur-fitur pada aplikasi tersebut.

Hasil analisis data pada penelitian ini juga menunjukan bahwa convenience motivation tidak memiliki pengaruh terhadap attitude towards online food delivery services. Hal ini karena konsumen merasa bahwa kemudahan dalam menggunakan aplikasi pemesanan kopi tidak serta merta membentuk sikap positif terhadap aplikasi tersebut, mengingat mayoritas responden pada penelitian ini adalah generasi muda yang sangat dekat dengan teknologi, sehingga sikap positif terhadap sebuah teknologi akan terbentuk bukan karena faktor kemudahan dalam menggunakan teknologi tetapi lebih pada faktor manfaat yang dirasakan ketika menggunakan sebuah teknologi. Temuan ini didukung pula oleh Lee et al., (2005) yang menyatakan bahwa convenience motivation tidak memiliki pengaruh yang signifikan terhadap attitude toward online food delivery. Masih terkait dengan convenience motivation hasil analisis data pada penelitian ini menunjukan bahwa convenience motivation tidak memiliki pengaruh terhadap post usage usefulness. Liu \& Li (2011) pada penelitianya juga menemukan bahwa convenience motivation tidak memiliki pengaruh terhadap post-usage usefulness. Kondisi ini terjadi ketika pengguna tidak hanya mengejar kemudahan dalam menggunakan sebuah aplikasi untuk mendapatkan manfaat yang diinginkan, tetapi pada penawaran potongan harga yang diberikan sehingga menarik konsumen untuk menggunakan aplikasi pemesanan kopi tersebut. Selain itu, pada penelitian ini juga menyatakan bahwa convenience motivation tidak memiliki pengaruh terhadap behavioral intention. Temuan dari Bashir \& Madhavaiah (2015) mendukung hasil penelitian ini, bahwa convenience motivation tidak memiliki pengaruh terhadap behavioral intention towards online food delivery. Mengingat responden pada penelitian ini mayoritas adalah generasi muda yang sudah terbiasa menggunakan sebuah teknologi, maka faktor kemudahan dalam menggunakan aplikasi bukan hal utama yang mendorong mereka untuk menggunakan sebuah aplikasi.

Untuk variabel post usage usefulness, dari hasil analisis data menunjukan pengaruh positif terhadap attitude towards online food delivery services. Yeo et al., (2017) pada penelitiannya juga menunjukan hasil yang sama, hal ini menggambarkan bahwa manfaat yang dirasakan konsumen ketika menggunakan sebuah aplikasi pemesanan minuman kopi dapat membentuk sikap positif konsumen terhadap aplikasi tersebut. Ketika konsumen merasa bahwa dengan menggunakan aplikasi tersebut tidak membuang waktu dalam memesan minuman kopi, ataupun tawaran harga yang lebih murah ketika memesan melalui aplikasi akan membuat 
konsumen merasa bahwa menggunakan aplikasi tersebut merupakan sebuah keputusan yang tepat. Meskipun pada penelitian ini post usage usefulness tidak memiliki pengaruh terhadap behavioral intention. Bashir \& Madhavaiah (2015) juga menyatakan bahwa manfaat yang dirasakan konsumen dari sebuah aplikasi tidak serta merta mendorong mereka untuk menggunakan aplikasi tersebut, tetapi harus di dukung oleh sikap positif terhadap aplikasi tersebut sehingga mendorong keinginan konsumen untuk menggunakan aplikasi untuk memesan minuman kopi.

Sikap positif dari seorang konsumen terhadap aplikasi pemesanan minuman kopi memiliki pengaruh terhadap behavioral intention. Liu \& Li (2011) dan Lee et al., (2006) pada penelitiannya juga menemukan hal yang sama. Ketika seorang konsumen lebih menyukai menggunakan aplikasi ketika memesan minuman kopi dari pada harus datang ke retail terdekat, maka akan mendorong keinginan konsumen untuk menggunakan aplikasi tersebut.

Pada penelitian ini menunjukan pula bahwa prior online purchase experience tidak menunjukan pengaruh positif terhadap convenience motivation dan post-usage usefulness. Hasil penelitian ini sejalan dengan Aziz \& Wahid (2018) yang menemukan hal yang sama bahwa prior online purchase experience tidak memiliki pengaruh yang signifikan terhadap convenience motivation. Selain itu penelitian dari Yeo et al., (2017) juga menunjukan bahwa prior online purchase experience tidak memiliki pengaruh yang signifikan terhadap post-usage usefulness. Hal ini terjadi karena konsumen tidak merasakan manfaat dari aplikasi tersebut melalui frekuensi atau pengalaman pembelian konsumen secara online sebelumnya, karena setiap aplikasi memiliki fitur yang berbeda-beda yang menuntut pengalaman yang berbeda, sehingga hal ini tidak dapat mendorong konsumen untuk menggunakan sebuah aplikasi.

Hedonic motivation tidak memiliki pengaruh terhadap convenience motivation dan postusage usefulness. Hubert et al., (2017) pada penelitiannya menyatakan bahwa hedonic motivation tidak memiliki pengaruh yang signifikan terhadap convenience motivation dan usefulness. Pada aplikasi pemesanan minuman kopi, aspek yang bersifat kesenangan atau hiburan tidak terlalu banyak muncul, sehingga ketika mengakses aplikasi tersebut pengguna tidak merasakan sisi emosional yang terbangun, pengguna lebih menutamakan aspek utilitarian yaitu fungsi utama dari aplikasi tersebut. Sehingga hal ini menjelaskan mengapa pada penelitian ini hedonic motivation tidak memiliki pengaruh terhadap persepsi konsumen terhadap manfaat dan kemudahan dalam menggunakan aplikasi tersebut.

Kesimpulan dari penelitian ini menunjukan bahwa time saving orientation dan price saving orientation memiliki pengaruh positif terhadap post usage usefulness dan attitude, yang kemudian dalam jangka panjang akan mempengaruhi behavioral intention. Hal ini menunjukan bahwa konsumen akan merasakan manfaat dari sebuah aplikasi jika aplikasi tersebut mampu menghemat waktu ketika melakukan pemesanan. Khususnya untuk pemesanan minuman kopi, konsumen dapat merasakan bahwa melalui aplikasi yang ada membuat konsumen lebih mudah dan lebih cepat dalam memilih dan memesan minuman kopi yang diinginkannya daripada harus menghabiskan waktu lebih lama dengan datang langsung ke retail terdekat. Selain itu, hasil penelitian ini juga menunjukan bahwa jika pemesanan yang dilakukan melalui aplikasi menawarkan paket potongan harga, hal ini akan membuat konsumen lebih memilih untuk membeli melalui aplikasi karena lebih menguntungkan dari sisi biaya yang harus dikeluarkan. Ketika biaya yang dikeluarkan semakin kecil maka konsumen akan merasakan manfaat yang lebih besar ketika memesan melalui aplikasi. Dari keseluruhan manfaat yang terbentuk dibenak konsumen terhadap aplikasi, maka akan membentuk sikap positif konsumen terhadap aplikasi tersebut. Hal ini tentu saja sangat diharapkan oleh pemilik aplikasi, karena sikap positif tersebut akan mendorong keinginan konsumen untuk menggunakan aplikasi tersebut. 


\subsection{Implikasi Manajerial}

Pada penelitian ini menunjukan bahwa untuk meningkatkan persepsi manfaat (postusage usefulness) dari sebuah aplikasi, dapat dilakukan dengan meningkatkan value melalui time saving orientation, ketika menggunakan aplikasi tersebut. Temuan ini sejalan dengan hasil penelitian dari Hossain et al., (2019). Hal ini menunjukan bahwa dengan menggunakan aplikasi Fore Coffee akan menghemat waktu yang dibutuhkan oleh konsumen dalam melakukan pemesanan minuman kopi. Untuk menciptakan persepsi tersebut dibenak konsumen, tentu harus didukung dengan layanan yang terstandarisasi sehingga waktu pemesanan untuk kopi tidak melebihi estimasi waktu yang diperkirkan pada aplikasi. Selain itu aplikasi Fore Coffee dapat pula menambah user interface dengan tipe pesanan pickup order agar dapat memberikan kepastian dari sisi waktu kapan pesanan kopi selesai dan dapat diambil oleh konsumen.

Selain time saving orientation terdapat variabel lain yang dapat digunakan untuk meningkatkan persepi manfaat (post-usage usefulness) yaitu price saving orientation. Hal ini sejalan dengan temuan dari Wei et al., (2018). Dari hasil analisis data tersebut membuktikan bahwa konsumen dapat lebih menghemat biaya ketika menggunakan aplikasi Fore Coffee dalam memesan kopi. Untuk meningkatkan hal tersebut Fore Coffee dalam periode tertentu dapat menawarkan beberapa promo untuk produk-produk tertentu seperti program paket minuman, terutama ketika penjualan dalam posisi kurang baik. Promo ini hanya dapat diakses melalui aplikasi saja, sehingga hal ini dapat memungkinkan untuk menarik pengguna aplikasi lebih banyak lagi karena promo tersebut hanya dapat diakses melalui aplikasi. Diharapkan dengan metode ini dapat mendorong angka penjualan dalam jangka pendek.

Pada penelitian ini juga diperoleh hasil bahwa, post-usage usefulness memiliki pengaruh positif terhadap attitude hal ini sejalan dengan penelitian dari Yeo et al., (2017). Untuk meningkatkan sikap positif pengguna terhadap aplikasi Fore Coffee, dapat dilakukan dengan meningkatkan persepsi manfaat di benak konsumen dalam memesan minuman kopi melalui aplikasi. Perusahaan dapat memberikan edukasi pada calon pengguna tentang manfaat yang dapat dirasakan konsumen jika memesan kopi Fore Coffee melalui aplikasi. Proses edukasi ini dapat dilakukan melalui kegiatan promosi seperti pemanfaatan media digital yaitu social media.

Hasil dari penelitian ini juga menunjukan bahwa sikap positif yang muncul dibenak konsumen dapat mendorong keinginan konsumen untuk menggunakan aplikasi Fore Coffee ketika akan memesan kopi. Temuan ini sejalan dengan temuan dari Liu \& Li (2011) yang menyatakan bahwa attitude memiliki pengaruh positif behavioral intention. Untuk itu guna meningkatkan keinginan seseorang untuk menggunakan aplikasi Fore Coffee dapat ditingkatkan melalui sikap positif konsumen, dengan cara melakukan edukasi di social media bahwa memesan kopi melalui aplikasi Fore Coffee di_masa pandemic ini merupakan keputusan yang benar, mengingat prioritas kesehatan adalah hal utama dan upaya untuk menghindari interaksi secara fisik. Sehingga diharapkan jumlah orang yang menggunakan aplikasi ini untuk memesan kopi menjadi lebih banyak

\subsection{Keterbatasan Penelitian}

Responden pada penelitian ini merujuk pada orang-orang yang telah mengakses aplikasi Fore Coffee namun belum pernah bertransaksi dengan menggunakan aplikasi tersebut ketika memesan kopi. Sedangkan penelitian ini ingin melihat faktor faktor yang mempengaruhi keinginan seseorang untuk menggunakan sebuah aplikasi. Untuk mendapatkan hasil yang lebih baik maka penelitian selanjutnya akan lebih baik jika responden adalah orang-orang yang telah mengakses dan bertransaksi dengan menggunakan aplikasi Fore Coffee ketika memesan minuman kopi. Sehingga diperoleh gambaran penelitian yang lebih baik. 


\section{REFERENSI}

Akbar, Caesar (2020, Agustus 11), Kemenprin Proyeksi Industri Makanan Tumbuh 3 Persen $\begin{array}{lllll}\text { Akhir } & 2020 & \text { Retrieved } & \text { Januari } & \text { From }\end{array}$ https://bisnis.tempo.co/read/1374738/kemenperin-proyeksi-industri-makananminuman-tumbuh-3-persen-akhir-2020-jika/full\&view=ok

Abd Aziz, N. N., \& Abd Wahid, N. (2018). Factors influencing online purchase intention among university students. International Journal of Academic Research in Business and Social Sciences, 8(7). Doi: 10.6007/IJARBSS/v8-i7/4413

Bashir, I., \& Madhavaiah, C. (2015). Consumer attitude and behavioural intention towards Internet banking adoption in India. Journal of Indian Business Research. Doi: https://doi.org/10.1108/JIBR-02-2014-0013

Bhattacherjee, A., Perols, J., Sanford, C., 2008b. Information technology Continuance: a theoretical extension and empirical test. J. Comput. Inf. Syst. 49 (1), 17-26.

Bellman, S., Lohse, G. L., \& Johnson, E. J. (1999). Predictors of online buying behavior. Communications of the ACM, 42(12), 32-38. doi:10.1145/322796.322805

Bendary, N., \& Al-Sahouly, I. (2018). Exploring the extension of unified theory of acceptance and use of technology, UTAUT2, factors effect on perceived usefulness and ease of use on mobile commerce in Egypt. Journal of Business and Retail Management Research, 12(2).

Catarina, Elsa (2019, November 11), Fore Coffee Genjot Penjualan Lewat Aplikasi dan Gandeng Airy. Retrived Januari 2021. From:

https://money.kompas.com/read/2019/11/20/170000326/fore-coffee-genjot-penjualanlewat-aplikasi-dan-gandeng-airy

Chang, C. C., Yan, C. F., \& Tseng, J. S. (2012). Perceived convenience in an extended technology acceptance model: Mobile technology and English learning for college students. Australasian Journal of Educational Technology, 28(5).

Chen, Y. Y. (2012). Why do consumers go internet shopping again? Understanding the antecedents of repurchase intention. Journal of Organizational Computing and Electronic Commerce, 22(1), $\quad$ 38-63. Doi: https://doi.org/10.1080/10919392.2012.642234

Chen, M., Hu, M., \& Wang, J. (2019). Food delivery service and restaurant: Friend or foe?. Available at SSRN 3469971.

Dahwilani, Dani. M (2019, Desember 17), Data dan Fakta Tren Menjamurnya Kedai Kopi Kekinian di Indonesia. Retrieved Januari 2021.From:https://www.inews.id/travel/kuliner/data-dan-fakta-tren-menjamurnyakedai-kopi-kekinian-di-indonesia

Dennis, C., Morgan, A., Wright, L. T., \& Jayawardhena, C. (2010). The influences of social eshopping in enhancing young women's online shopping behaviour. Journal of Customer Behaviour, 9(2), 151-174. doi:10.1362/147539210x511353

Dinda, Sanya (2020, September 15), Konsumsi Kopi di Indonesia Naik 44\% . Retrieved Januari 2021. From: https://investor.id/business/konsumsi-kopi-di-indonesia-naik-44

Ernst, C. P. H., Pfeiffer, J., \& Rothlauf, F. (2013). Hedonic and utilitarian motivations of social network site adoption. Johannes Gutenberg University Mainz: Working Papers in Information Systems and Business Administration, 1-14. 
Fagan, M. H., Neill, S., \& Wooldridge, B. R. (2008). Exploring the intention to use computers: An empirical investigation of the role of intrinsic motivation, extrinsic motivation, and perceived ease of use. Journal of Computer Information Systems, 48(3), 31-37.

Hair, J. F., Black, W. C., Babin, B. J., \& Anderson, R. E. (2010). Multivariate Data Analysis 7th Edition Pearson Prentice Hall.

Hossain, R., Mahmud, S. H., Hossin, M. A., Bhuiyan, T., \& Hua, Y. X. (2019). Effects of Cognitive Ability, Trust and Time-Saving: Predicting Further Amelioration and Successive Usage of E-ticketing with TAM, TPB and Cognitive Frameworks. In Information and Communication Technology for Competitive Strategies (pp. 41-51). Springer, Singapore. Doi: https://doi.org/10.1007/978-981-13-0586-3_5

Hubert, M., Blut, M., Brock, C., Backhaus, C., \& Eberhardt, T. (2017). Acceptance of smartphone-based mobile shopping: Mobile benefits, customer characteristics, perceived risks, and the impact of application context. Psychology \& Marketing, 34(2), 175-194.

Hwang, J., Lee, J. S., \& Kim, H. (2019). Perceived innovativeness of drone food delivery services and its impacts on attitude and behavioral intentions: The moderating role of gender and age. International Journal of Hospitality Management, 81, 94-103.

Kimes, S.E., 2011. The Current state of online food ordering in the U.S. Restaurant Industry. Cornell Hosp. Rep. 11 (17), 6-18.

Kim, J., \& Forsythe, S. (2010). Factors affecting adoption of product virtualization technology for online consumer electronics shopping. International Journal of Retail \& Distribution Management. Doi: https://doi.org/10.1108/09590551011027122

Kim, M. J., Chung, N., Lee, C. K., \& Preis, M. W. (2015). Motivations and use context in mobile tourism shopping: Applying contingency and task-technology fit theories. International Journal of Tourism Research, 17(1), 13-24. Doi: 10.1002/jtr.1957

Kim, K. J. (2016). Round or square? How screen shape affects utilitarian and hedonic motivations for smartwatch adoption. Cyberpsychology, Behavior, and Social Networking, 19(12), 733-739. Doi: https://doi.org/10.1089/cyber.2016.0136

Lee, S. W., Sung, H. J., \& Jeon, H. M. (2019). Determinants of continuous intention on food delivery apps: extending UTAUT2 with information quality. Sustainability, 11(11), 3141. Doi: 10.3390/su11113141

Lee, M. K., Cheung, C. M., \& Chen, Z. (2005). Acceptance of Internet-based learning medium: the role of extrinsic and intrinsic motivation. Information \& management, 42(8), 10951104

Lee, H. H., Fiore, A. M., \& Kim, J. (2006). The role of the technology acceptance model in explaining effects of image interactivity technology on consumer responses. International Journal of Retail \& Distribution Management. Doi: https://doi.org/10.1108/09590550610675949

Lee, E. Y., Lee, S. B., \& Jeon, Y. J. J. (2017). Factors influencing the behavioral intention to use food delivery apps. Social Behavior and Personality: an international journal, 45(9), 1461-1473.

Li, M., \& Cai, L. A. (2012). The Effects of Personal Values on Travel Motivation and Behavioral Intention. Journal of Travel Research, 51(4), 473-487. https://doi.org/10.1177/0047287511418366 
Liu, Y., \& Li, H. (2011). Exploring the impact of use context on mobile hedonic services adoption: An empirical study on mobile gaming in China. Computers in Human Behavior, 27(2), 890-898. Doi: https://doi.org/10.1016/j.chb.2010.11.014

Li, Y. H., \& Huang, J. W. (2009). Applying theory of perceived risk and technology acceptance model in the online shopping channel. World Academy of Science, Engineering and Technology, 53(1), 919-925.

Madan, V., Suri, R., 2001. Quality perception and monetary sacrifice\$: a comparative analysis of discount and fixed prices. J. Prod. Brand Manag. 10 (3), 170-184.

Mediaindonesia, (2019, Mei 4), Nyopee Bidik Potensi Bisnis Coffee to Go. Retrieved: Februari 2021.From:https://mediaindonesia.com/ekonomi/233503/nyopee-bidik-potensi-bisniscoffee-to-go

Mohamed, N., Hussein, R., Zamzuri, N. H. A., \& Haghshenas, H. (2014). Insights into individual's online shopping continuance intention. Industrial Management \& Data Systems. Doi: https://doi.org/10.1108/IMDS-07-2014-0201

Nedra, B. A., Hadhri, W., \& Mezrani, M. (2019). Determinants of customers' intentions to use hedonic networks: The case of Instagram. Journal of Retailing and Consumer Services, 46, 21-32. Doi: https://doi.org/10.1016/j.jretconser.2018.09.001

Nordiansyah, Eko (2021, Februari 27), Bisnis Layanan Pesan Antar Makanan Online Meningkat Selama Pandemi. Retrieved Maret 2021. From:

https://www.medcom.id/ekonomi/bisnis/8kolVnWK-bisnis-layanan-pesan-antarmakanan-online-meningkat-selama-pandemi

Novita, D., \& Husna, N. (2020). THE INFLUENCE FACTORS OF CONSUMER BEHAVIORAL INTENTION TOWARDS ONLINE FOOD DELIVERY SERVICES. TECHNOBIZ: International Journal of Business, 3(2), 40-42.

Nurdiana, Avanty (2020, Mei 19), Pandemi Virus Corona membuat Fore Coffe tutup 20 kedai kopi secara permanen. Retrieved Januari 2021. From:

https://peluangusaha.kontan.co.id/news/pandemi-virus-corona-membuat-fore-coffetutup-20-kedai-kopi-secara-permanen

Prabowo, G. T., \& Nugroho, A. (2019, March). Factors that Influence the Attitude and Behavioral Intention of Indonesian Users toward Online Food Delivery Service by the Go-Food Application. In 12th International Conference on Business and Management Research (ICBMR 2018). Atlantis Press

Park, C., \& Jun, J. K. (2003). A cross-cultural comparison of Internet buying behavior. International Marketing Review. Doi: 10.1108/02651330310498771

Park, E., \& Kim, K. J. (2013). User acceptance of long-term evolution (LTE) services. Program, 47(2), 188-205. doi:10.1108/00330331311313762

Partridge, S. R., Gibson, A. A., Roy, R., Malloy, J. A., Raeside, R., Jia, S. S., Redfern, J. (2020). Junk Food on Demand: A Cross-Sectional Analysis of the Nutritional Quality of Popular Online Food Delivery Outlets in Australia and New Zealand. Nutrients, 12(10), 3107. doi:10.3390/nu12103107

Purnamaningsih, P., Erhan, T. P., \& Rizkalla, N. (2019). BEHAVIORAL INTENTION TOWARDS APPLICATION-BASED SHORT-DISTANCE DELIVERY SERVICES ADOPTION IN INDONESIA. Review of Behavioral Aspect in Organizations and Society, 1(1), 77-86. https://doi.org/10.32770/rbaos.vol177-86 
Ramayah, T., Jantan, M., Mohd Noor, M. N., Razak, R. C., \& Koay, P. L. (2003). Receptiveness of internet banking by Malaysian consumers: The case of Penang. Asian Academy of Management Journal, 8(2), 1-29.

Rodrigues, L. F., Oliveira, A., \& Costa, C. J. (2016). Does ease-of-use contributes to the perception of enjoyment? A case of gamification in e-banking. Computers in Human Behavior, 61, 114-126. Doi: https://doi.org/10.1016/j.chb.2016.03.015

Saadé, R. G., \& Kira, D. (2007). Mediating the impact of technology usage on perceived ease of use by anxiety. Computers \& education, 49(4), 1189-1204. Doi: https://doi.org/10.1016/j.compedu.2006.01.009

Saarijärvi, H., Mitronen, L., Yrjölä, M., 2014. From selling to supporting - leveraging mobile services in the context of food retailing. J. Retail. Consum. Serv. 21 (1), 26-36.

Suhartanto, D., Helmi Ali, M., Tan, K. H., Sjahroeddin, F., \& Kusdibyo, L. (2019). Loyalty toward online food delivery service: the role of e-service quality and food quality. Journal of foodservice business research, 22(1), 81-97.

Sun, H., \& Zhang, P. (2006). Causal relationships between perceived enjoyment and perceived ease of use: An alternative approach. Journal of the Association for Information Systems, 7(1), 24.

Teo, T., \& Noyes, J. (2011). An assessment of the influence of perceived enjoyment and attitude on the intention to use technology among pre-service teachers: A structural equation modeling approach. Computers \& education, 57(2), 1645-1653. Doi: 10.1016/j.compedu.2011.03.002

Thomas, Vincent Fabian (2019, September 19), Nielsen: 58\% Masyarakat Pesan Makanan via Aplikasi Pesan-Antar, Retrieved Januari 2021. From: https://tirto.id/eil7

Tong, X. (2010). A cross-national investigation of an extended technology acceptance model in the online shopping context. International Journal of Retail \& Distribution Management, 38(10), 742-759. doi:10.1108/09590551011076524

Wei, Z., Lee, M. Y., \& Shen, H. (2018). What drives consumers in China to buy clothing online? Application of the technology acceptance model. Journal of Textiles and Fibrous Materials, 1, 2515221118756791. Doi: https://doi.org/10.1177\%2F2515221118756791

Yeo, V. C., Goh, S., \& Rezaei, S. (2017). Consumer experiences, attitude and behavioral intention toward online food delivery (OFD) services. Journal of Retailing and Consumer Services, 35, 150-162. doi:10.1016/j.jretconser.2016.12.013

Yusra, Yenny (2020, April 20), Berhasil Kumpulkan Dana 147 Miliar Rupiah, Fore Coffee Genjot Ekspansi. Retrieved Januari 2021. From: https://dailysocial.id/post/ekspansifore-coffee

Venkatesh, Viswanath, et al. "User acceptance of information technology: Toward a unified view." MIS quarterly (2003): 425-478.

Venkatesh, Thong, \& Xu. (2012). Consumer Acceptance and Use of Information Technology: Extending the Unified Theory of Acceptance and Use of Technology. MIS Quarterly, 36(1), 157. doi: $10.2307 / 41410412$

Xu, X., \& Finland, F. (2014). Understanding users' continued use of online games: An application of UTAUT2 in social network games. MMEDIA 2014. 